\title{
WACC as the minimization criterion of liability management in a company capital structure optimization
}

\author{
Jaroslav JAROŠ ${ }^{1, a *}$, Vlastimil MELICHAR ${ }^{2, b}$, Libor ŠVADLENKA ${ }^{3, c}$ \\ 1,2,3 University of Pardubice, Jan Perner Transport Faculty, Studentská 95, 532 10, Pardubice, \\ Czech Republic

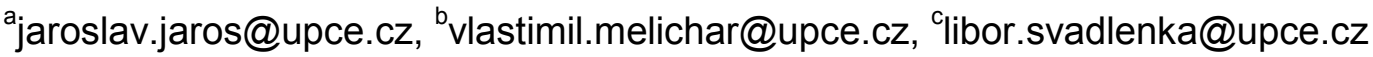

\begin{abstract}
Keywords: model CAPM, cost of capital, beta coefficient, capital market, capital structure optimization.
\end{abstract}

\begin{abstract}
In our study we concern with the quantification of the weighted average cost of capital, as the minimization criterion for the company capital structure optimization. To achieve more accurate estimation of the costs of capital we calculated them using four models with weights assigned on the basis of their explanatory power of the particular company. In the next step, the possibility of application of individual models and their explanatory power in the countries with poorly developed capital markets, where the necessary data for the calculations absent and there is the impact of the financial crisis, is determined. Our aim in further research is to design company liability management methodology which contains other optimization criteria.
\end{abstract}

\section{Introduction}

One of the biggest problems of individual theories of the capital structure is that it is very difficult to establish a mathematical dependence (curve) of the company weighted average cost of capital on various changes of the capital structure. However, a rough optimum level of the company capital composition may be found out. The prerequisite is to quantify properly the costs of particular forms of the company capital from the perspective of a reasonable estimation of the optimal level using WACC. The first component is the cost of equity which is in our work calculated by four models with weights assigned on the basis of their expressing power of the particular company doing business in Slovakia. The second component is the cost of debt capital.

We choose this minimization criterion as a decision-making criterion to optimize the capital structure of the company at the given stage of our methodology. It is based on the minimizing of the weighted average cost of capital (WACC).

\section{Results}

The precise quantification of the cost of equity $(\mathrm{Re})$ should be based on a number of publications, including the foreign ones, but so far there has been a lack of comprehensive review. In the literature we encounter empirical research mostly from Anglo-Saxon countries, which our authors only alter without any thorough analysis, empirical review and adaptation to specific conditions in the Slovak Republic. Therefore, our results of the work are described in detail and are calculated in the Slovak capital market conditions. The use of CAPM is in practice very difficult mainly because the model requires the completion of a number of assumptions that are not met even in the most developed countries. We tested its explanatory power applying the model in the underdeveloped capital market of the Slovak Republic. We did not borrow the beta coefficient but we calculated it for a particular capital market and a company based on the historical stock prices and historical prices of global index. The method of least squares was applied for these values. This value was then adjusted according to the debt in each year.

To quantify the cost of equity we used the following four models: the INFA model of the Neumaiers, the CAPM model, the P/E model and the calculation of the cost of equity using ROE. 
To quantify the cost of debt capital, we used the average interest rate on loans provided by commercial banks and the calculation using the company interest costs.

The first alternative of the cost of equity calculation was performed using the model INFA of the Neumaiers. Along with the model of complex build-up method there are an example of a build-up models that allow to extend risk premium of other components. Specific feature and also the advantage of this methodology is that the calculation is not dependent on the market evaluation of an enterprise [1]. The costs of equity are determined as the sum of the risk-free rate of return and the risk premium: the risk premium consists of four components, which are determined on the basis of selected ratios calculated for the enterprise. The risk premium includes both systematic and specific risk. Although the model is not tailored to the needs of the Slovak enterprises, it can be used after several modifications [6,7].

The final amount of the cost of equity is expressed by the formula:

$\mathrm{R}_{\mathrm{e}}=\mathrm{r}_{\mathrm{f}}+\mathrm{r}_{\mathrm{LA}}+\mathrm{r}_{\text {comp }}+\mathrm{r}_{\mathrm{fin}}+\mathrm{r}_{\mathrm{fs}}$

Unlike the other models, the INFA model provides the costs of equity differentiated according to the period of the chosen indicators value calculation. Individual values of the cost of equity calculated using the build-up method of the INFA model for the reference years are depicted in Table 1.

Table 1 Cost of equity

\begin{tabular}{|l|r|r|r|r|}
\hline Year & $\mathbf{2 0 1 0}$ & $\mathbf{2 0 1 1}$ & $\mathbf{2 0 1 2}$ & $\mathbf{2 0 1 3}$ \\
\hline $\mathrm{r}_{\mathrm{f}}(\%)$ & 4,49 & 4,72 & 4,7 & 3,87 \\
\hline $\mathrm{r}_{\mathrm{LA}}(\%)$ & 3,84 & 3,64 & 3,47 & 3,10 \\
\hline $\mathrm{r}_{\text {fin }}(\%)$ & 3,84 & 1,02 & 0 & 0 \\
\hline $\mathrm{r}_{\text {comp }}(\%)$ & 10 & 0 & 0 & 0 \\
\hline $\mathrm{r}_{\text {fs }}(\%)$ & 10 & 0 & 0 & 0 \\
\hline $\operatorname{Re}(\%)$ & 32,17 & 9,38 & 8,17 & 6,97 \\
\hline
\end{tabular}

\section{CAPM model}

Another alternative of the cost of equity calculation is the CAPM model. To calculate the cost of equity using this method we need to define three variables of the model: risk-free rate, risk premium of the capital market and the $\beta$ coefficient.

Risk-free interest rate is, in this paper, expressed as the average annual yield to maturity of the Slovak government bonds which maturities was 10 years in the given month.

The calculation of the risk premium of the Slovak capital market is based on the average monthly returns of the SAX index, converted to their annual values.

Table 2 Annual return of the SAX index

\begin{tabular}{|l|c|c|c|c|c|c|c|c|c|c|c|r|r|}
\hline Year & $\mathbf{2 0 0 0}$ & $\mathbf{2 0 0 1}$ & $\mathbf{2 0 0 2}$ & $\mathbf{2 0 0 3}$ & $\mathbf{2 0 0 4}$ & $\mathbf{2 0 0 5}$ & $\mathbf{2 0 0 6}$ & $\mathbf{2 0 0 7}$ & $\mathbf{2 0 0 8}$ & $\mathbf{2 0 0 9}$ & $\mathbf{2 0 1 0}$ & AP & GP \\
\hline $\begin{array}{l}\text { SAX } \\
2000-\end{array}$ & & & & & & & & & & & & & \\
2010 & 19,20 & 19,20 & 15,90 & 26,90 & 83,90 & 26,50 & 0,60 & 7,23 & $-19,40$ & $-25,67$ & $-13,71$ & 12,79 & 9,45 \\
\hline
\end{tabular}

Source: www.bsse.sk

Firstly, the calculation was realized for the period 2007 - 2010, where the risk premium was negative. The reason of this decline was the negative value of the stock markets due to the economic and financial crisis of 2007 - 2009, and since 2008 we have observed annual falls of the stocks and shares. We are in an unusual situation which happened only occasionally before the crisis- the overall market risk premium is negative. Therefore, the resulting values do not have sufficient explanatory power. To minimize the impact of the global economic crisis that greatly distorted the resulting data, we calculate the SAX index for the period $2000-2010$. The second option would be 
to use an alternative index, but we should also consider longer period of time, because there is no index which was not affected by the crisis, only the index, which quickly gets to its pre-crisis value. Such indices are, for instance S\&P 500 and NASDAQ 100, which have almost acquired their precrisis values. But, it is not possible to compare SAX and PX indices, which are the indices of underdeveloped capital market, with Standard \& Poor's 500 index which is considered to be the standard measure of the US stock market performance.

Weaknesses of the SAX index are both poorly developed capital market in which the index operates and also the low number of index components, in consequence of which the development of one of the components very often has a significant impact on the development of the entire index. We even cannot work with the data of the whole period of the stock exchange (either BCPB or $\mathrm{BCPP}$ ) existence, as they do not have high predictive value, mainly due to the high inflation in the nineties, when the risk-free rate was $7-10 \%$ and so the market risk premium reached minimal or negative values. For the Slovak capital market is therefore possible to obtain the relevant data only from the last ten years. The following tables show the market risk premium calculated from the data of the USA, the Czech and the Slovak capital markets using the arithmetic and geometric mean. To calculate the risk premium of the US market we have to add the current surcharge of the country risk, which currently represents the value of $1.28 \%$. This value, however, is not included in the calculations of the Czech capital market. The reason is the identical score of both countries [2].

Table 3 Market risk premium calculated by the arithmetic mean

\begin{tabular}{|l|l|l|l|l|l|}
\hline Arithmetic mean & $\begin{array}{l}\text { Return of } \\
\text { shares in } \\
\text { \% }\end{array}$ & $\begin{array}{l}\text { Return of } \\
\text { bond in \% }\end{array}$ & $\begin{array}{l}\text { Market risk } \\
\text { premium in } \\
\%\end{array}$ & $\begin{array}{l}\text { Surcharge of } \\
\text { country risk in } \\
\%\end{array}$ & $\begin{array}{l}\text { Total market } \\
\text { risk premium } \\
\text { in \% }\end{array}$ \\
\hline $\begin{array}{l}\text { S\&P 500 1928 - } \\
\text { 2006 }\end{array}$ & 11,77 & 5,20 & 6,57 & 1,28 & 7,85 \\
\hline $\begin{array}{l}\text { S\&P 500 1966- } \\
\text { 2006 }\end{array}$ & 11,61 & 7,48 & 4,13 & 1,28 & 5,41 \\
\hline $\begin{array}{l}\text { S\&P 500 1996- } \\
\text { 2006 }\end{array}$ & 11,06 & 5,92 & 5,14 & 1,28 & 6,42 \\
\hline PX 1994- 2007 & 7,27 & 6,80 & 0,47 & 0 & 0,47 \\
\hline PX 1997 - 2007 & 16,84 & 5,89 & 10,95 & 0 & 10,95 \\
\hline $\begin{array}{l}\text { S\&P 500 2007 - } \\
\text { 2011 }\end{array}$ & $-0,25$ & 5,12 & $-5,37$ & 1,28 & $-4,09$ \\
\hline SAX 2007 - 2010 & $-12,89$ & 4,45 & $-17,34$ & 0 & $-17,34$ \\
\hline SAX 2000 - 2010 & 12,79 & 4,47 & 8,32 & 0 & 8,32 \\
\hline
\end{tabular}

Source: own-processing

Table 4 Market risk premium calculated by the geometric mean

\begin{tabular}{|l|l|l|l|l|l|}
\hline Geometric mean & $\begin{array}{l}\text { Return of } \\
\text { shares in } \\
\text { \% }\end{array}$ & $\begin{array}{l}\text { Return of } \\
\text { bond in \% }\end{array}$ & $\begin{array}{l}\text { Market risk } \\
\text { premium in } \\
\text { \% }\end{array}$ & $\begin{array}{l}\text { Surcharge of } \\
\text { country risk } \\
\text { in \% }\end{array}$ & $\begin{array}{l}\text { Total market } \\
\text { risk premium } \\
\text { in \% }\end{array}$ \\
\hline S\&P 500 1928-2006 & 9,86 & 4,95 & 4,91 & 1,28 & 6,19 \\
\hline S\&P 500 1966-2006 & 10,34 & 7,08 & 3,26 & 1,28 & 4,54 \\
\hline S\&P 500 1996-2006 & 9,56 & 5,67 & 3,89 & 1,28 & 5,17 \\
\hline PX 1994 - 2007 & 4,28 & 6,71 & $-2,43$ & 0 & $-2,43$ \\
\hline PX 1997 - 2007 & 13,62 & 5,75 & 7,87 & 0 & 7,87 \\
\hline SAX 2007 - 2010 & 0,61 & 4,24 & $-3,63$ & 0 & $-3,63$ \\
\hline SAX 2000 - 2010 & 9,45 & 4,21 & 5,24 & 0 & 5,24 \\
\hline
\end{tabular}

Source: own-processing

$B$ coefficient 
When calculating the $\beta$ coefficient a number of criteria have to be determined, for instance, the length of the period. In the USA the period of 2-5 years is used. A longer period allows to use more data, but the older the data, the weaker their importance. We choose a 4-year period, years 20072010 and we pursue the results of the company in this period. It is also necessary to choose the period of returns calculation. It is possible to choose an interval from a day to a year. We use the annual interval.

Finally, it is necessary to choose the right stock market index. In Germany the DAX is used, in the UK they use FTSE, NYSE is used in the USA, etc. We use the official share index of BCPB Slovak Share Index (SAX). It is a capital-weighted index that reflects the overall change of assets associated with investments in stocks included in the index. Except for price changes, the index includes dividend income and revenues related to the total capital changes. This index is based on the average prices specified in the exchange rate lists and it reflects only the development on the $\mathrm{BCPB}$. The disadvantage of the SAX index is the low number of companies involved in the index (the higher the number of companies, the more relevant the results). The size of the market capitalization, of the companies included in the index, have to be considered. The main reason of the use of this index is that the chosen company is traded on this stock market and our aim is to establish their interdependence.

For individual sectors the value of the $\beta$ coefficient may be found on the web pages of A. Damodaran (www.damodaran.com) in the "Updated Data" section, but only the values for the whole Europe. To get the value of the $\beta$ coefficients (for the Slovak capital market) is unrealistic, as the number of traded stocks is lower than the number of sectors (industries). Also there is no industry where such a parameter may be established (i.e. the sector is presented on the stock exchange by 2 or more titles). The calculated $\beta$ values therefore do not have such an explanatory power than the $\beta$ coefficient calculated from the data of the developed capital markets. We can conclude that discussed values of the industry have greatly distorted explanatory power. The $\beta$ coefficient of similar businesses is necessary to adjust of the effect of the capital structure in order to obtain corresponding information in the parameter of systematic risk of a particular company [8].

The sources to calculate the actual value of the coefficient $\beta$ are both historical stock prices and historical value of the global index. Then the method of the least squares is applied. The value of $\beta$ is then 0.165 .

Our goal was to find the most real $\beta$ values of the enterprise and therefore the coefficient was adjusted according to the current debt in each of the chosen years. The $\beta$ coefficient is of really low value. The reason was the bad situation on the capital market resulting in a weak dependence of company shares and market shares. The impact of the debt on the $\beta$ coefficient of the enterprise can be expressed by the following equation $[3,4]$ :

$$
\beta_{Z}=\beta_{N} \cdot\left(1+(1-d) \cdot \frac{C K}{V K}\right)-\beta_{C K}\left(\frac{C K}{V K}\right) \cdot(1-d)
$$

where

$\beta_{Z} \quad \beta$ coefficient of equity of the company in the debt,

$\beta_{N} \quad \beta$ coefficient of equity of the company in no debt,

$\beta_{C K} \quad \beta$ coefficient of debt,

$\mathrm{d}$ income tax rate,

CK debt in currency units,

VK equity in currency units

$\beta \quad$ should be dependent on industry and operating leverage. $\beta_{C K}$ is mostly considered to be zero, then:

$$
\beta_{Z}=\beta_{N}\left(1+(1-d) \frac{C K}{V K}\right)
$$


The calculated $\beta(0,165)$ can be modified for the company financed only by equity and so we get the zero value:

$$
\beta_{N}=\frac{\beta_{Z}}{\left(1+(1-d) \cdot \frac{C K}{V K}\right)}=\frac{0,165}{(1+0,81 \cdot 0,438)}=0,122
$$

The zero value of $\beta$, when no debt is considered, is then 0,122 . Then the $\beta$ coefficient for the debt to equity ratio may be set using the formula. The results of costs of equity for particular years calculated by CAPM are depicted in the Table 5. Financial and economic crisis influences the results a lot and this is the reason why the results of CAPM model are of a low importance.

Table 5 Cost of equity calculated by CAPM method

\begin{tabular}{|l|l|l|l|l|l|}
\hline Year & $\mathbf{2 0 1 0}$ & $\mathbf{2 0 1 1}$ & $\mathbf{2 0 1 2}$ & $\mathbf{2 0 1 3}$ & AM \\
\hline $\begin{array}{l}\text { Rate of return of capital market \% } \\
\text { (vi) }\end{array}$ & 7,23 & $-19,4$ & $-25,67$ & $-13,71$ & $-12,89$ \\
\hline $\begin{array}{l}\text { Rate of return of company shares \% } \\
\text { (vt) }\end{array}$ & $-4,07$ & 7,05 & $-32,59$ & 117,88 & 22,06 \\
\hline rf (\%) & 4,49 & 4,72 & 4,7 & 3,87 & 4,45 \\
\hline Beta (coefficient) & 0,173 & 0,169 & 0,163 & 0,158 & 0,165 \\
\hline Re (\%) & $\mathbf{5 , 9 3}$ & $\mathbf{6 , 1 3}$ & $\mathbf{6 , 0 6}$ & $\mathbf{5 , 1 8}$ & $\mathbf{5 , 8 2}$ \\
\hline
\end{tabular}

The dividend model cannot be used to quantify the cost of equity because the company does not pay any dividends in the reporting period.

The calculation of the cost of equity was extended of the approach based on the $\mathrm{P} / \mathrm{E}$ indicator (Price-Earnings Ratio). This model assumes zero growth of profits and utter dividend payout ratio. Unlike the CAPM model, the emphasis is given to the total company risk (systematic and unsystematic). Another way of cost of equity calculation was the estimation based on return on equity (ROE).

The resulting value of cost of equity is the weighted average of the individual methods. The weights were determined on the basis of the explanatory power of each model, for the year 2010INFA model (65\%), CAPM model (35\%), for 2011- INFA model (55\%), CAPM model (35\%) and ROE (10\%), for 2012 and 2013: INFA model (55\%), CAPM model (35\%), ROE (5\%), P / E (5\%).

In the methods, where costs of equity were estimated only with respect to the systemic risk, it is appropriate to add the additional risk premiums, such as the company size, liquidity of shareholding, rate of profit and its predictability, quality of management, the extent of diversification - product and customer oriented. Explanatory power of each model is expressed by their weights, so we do not add any risk surcharge.

The final value of the cost of equity is adjusted only of the effects of economic and financial crisis, which has brought an increased risk and volatility in capital markets. The financial and economic crisis has paralyzed the global capital market to such an extend that nowadays it is not easy to follow the indices, procedures and theories that had stood before.

Therefore, we do not differentiate individual years and we use the same surcharge. It also includes the surcharge of the risk-free interest rate and the surcharge for the reduced explanatory power of each model affected by the financial crisis, the surcharge is set at the level of $4 \%$.

The resulting value of the cost of equity is the weighted average of the individual methods. Weights were determined on the basis of the explanatory power of different models which are described in detail in the study. 
Table 6 Costs of equity

\begin{tabular}{|l|r|r|r|r|}
\hline Year & $\mathbf{2 0 1 0}$ & $\mathbf{2 0 1 1}$ & $\mathbf{2 0 1 2}$ & $\mathbf{2 0 1 3}$ \\
\hline P/E (\%) & - & $-7,23$ & 29,55 & 12,7 \\
\hline CAPM (\%) & 5,93 & 6,13 & 6,06 & 5,18 \\
\hline INFA (\%) & 32,17 & 9,38 & 8,17 & 6,97 \\
\hline ROE (\%) & - & 11,22 & 10,60 & 19,67 \\
\hline Weighted arithmetic mean (\%) & 22,83 & 8,10 & 7,58 & 8,41 \\
\hline Margin (\%) & 4 & 4 & 4 & 4 \\
\hline Re (\%) & $\mathbf{2 6 , 8 3}$ & $\mathbf{1 2 , 1 0}$ & $\mathbf{1 1 , 5 8}$ & $\mathbf{1 2 , 4 1}$ \\
\hline
\end{tabular}

However, the estimations of the different composition of the company capital, which could be used to determine an optimal ratio of debt and equity in company liabilities, will not be realized. Optimal debt is quantified in the following research using other methods proposed in our methodology.

\section{Cost of debt quantification}

The gradual reduction of the interest rates in the Slovak economy allows enterprises to reduce interest costs related to the debt and thus the riskiness of their business (reducing the cost of equity). Lower cost of capital meant, mainly in the pre-crisis period, the acceptance of such investment projects that would have been declined in the past because of the high costs of capital. The phenomenon has a positive effect on business performance.

Table 7 Cost of debt

\begin{tabular}{|l|r|r|r|r|}
\hline Year & $\mathbf{2 0 1 0}$ & $\mathbf{2 0 1 1}$ & $\mathbf{2 0 1 2}$ & $\mathbf{2 0 1 3}$ \\
\hline IR (\%) & 5,72 & 5,6 & 3,99 & 3,97 \\
\hline Surcharge (\%) & 2 & 2 & 2 & 2 \\
\hline Cost of debt (\%) & 7,72 & 7,6 & 5,99 & 5,97 \\
\hline
\end{tabular}

Source: www.nbs.sk

The following table shows the average cost of capital of the company in the chosen years. In 2007 , the cost of capital of the company was almost $16 \%$. It was caused by the poor financial results. In the other years the company achieves almost identical values at around $9 \%$.

Table 8 Weighted average cost of capital

\begin{tabular}{|l|r|r|r|r|}
\hline Year & $\mathbf{2 0 1 0}$ & $\mathbf{2 0 1 1}$ & $\mathbf{2 0 1 2}$ & $\mathbf{2 0 1 3}$ \\
\hline WACC (\%) & 15,59 & 9,18 & 8,71 & 9,68 \\
\hline
\end{tabular}

Source: own-processing

\section{Conclusions}

Management of liabilities in the Slovak Republic is mostly focused only on the basic rules of financing. This issue is significantly influenced by the underdeveloped capital market, particularly the stock market, which is used very occasionally as a source of financing. Slovakia belongs to the economies with a strong predominance of bank credit to the issue of the debt in the capital market. This is primarily a tradition of funding, with concern about the control of the company by shareholders, information obligations and greater legal protection of banks than of investors. Other weaknesses in the theoretical sphere are ambiguity in the use of basic terms (capital or financial structure), disunity on the definition of the optimal debt ratio, unrealistic assumptions of capital structure models, the lack of the data needed for calculations, uselessness in conditions of the Slovak enterprises, uselessness in the conditions of the financial crisis, etc.

The modern financial economists have to state, on the basis of the empirical and theoretical studies, that the generally valid theory of capital structure of the company does not exist. The validity of any 
theory is contingent by the acceptance of conditions, which are in the case of individual theories formulated as the basic conditions for their validity. For that reason the company cannot make decisions about the capital structure on the basis of a single criterion, but the optimal level of the debt has to be decided based on the analysis of all key factors that influence the company and its capital structure.

We also have to point out that it has not been conducted any deeper analysis of practical utility of various theories of capital structure in the specific conditions of the Czech Republic and the Slovak Republic and so the validity of their conclusions has been neither confirmed nor rejected. This is the reason of the missing conclusions and recommendations of various theories of capital structure. The consequence is the lack of definition of relations of the liability management in the business system Slovak enterprises management. The application of theoretical and methodological approaches that could belong to the management of liabilities is realized only in the context of the financial analysis. Our goal in the follow-up research is to devise a methodology of the capital structure optimization consisting of multiple optimization criteria. One of the evaluation steps in the devised methodology is already implemented quantification of weighted average cost of capital - WACC which will act in our model as a minimization criterion. The next step in the proposed methodology will be the maximization criterion (EVA indicator) and the construction of a statistical model to determine the impact of potential determinants on the capital structure of the company.

\section{References}

[1] V. Bartošová: Optimization of the financial structure of the company, University of Žilina/EDIS - ŽU, Žilina 2005. ISBN 80-8070-404-X (Optimalizácia finančnej štruktúry podniku)

[2] J., Jaroš: Management of company liabilities in a free market environment, $\mathrm{PhD}$ Thesis, University of Žilina. Žilina. Slovakia. 2012 (Riadenie podnikových pasív v podmienkach vol'ného trhu)

[3] M. Mařík: Determining the value of companies, Ekopress, Praha 1998, ISBN 80-86119-09-2 (Určování hodnoty firem)

[4] M. Mařík, P. Maříková: Modern methods of performance assessment and business valuation. Ekopress, Praha 2005, ISBN 80-86119-61-0 (Moderní metody hodnocení výkonnosti a oceňování podniku)

[5] F. MODigliani, M. H. MiLlER: Corporate Income Taxes and the Cost of Capital: A Correction. The American Economic Review, 1963, roč. 53, č. 3, s. 433-443

[6] I. Neumaierová, I. Neumaier: Reflection on the optimal debt. Finance and debt, v. 1, 1996. ISSN 0015 -1920. pp. 51 - 61 (Úvaha o optimální zadluženosti)

[7] I. Neumaierová, I. Neumaier Performance and market value of the firm. GRADA Publishing, Praha 2002. ISBN 80-247-0125-1 (Výkonnost a tržní hodnota firmy)

[8] T. Klieštik, A.N. Lyakin, K. Valašková: Stochastic calculus and modelling in economics and finance. In: Economics and social science : 2nd international conference on economics and social science (ICESS 2014) : July 29-30, 2014, Shenzhen, China. - Newark: Information Engineering Research Institute, 2014. - ISBN 978-1-61275-068-2. - S.161-167.- (Advances in education research, Vol. 61. - ISSN 2160-1070). (Stochastický kalkulus a modelovanie v ekonómii a financiách). 